\title{
Identification of Honey Bee Floras and Their Flowering Times in Wondo Genet, Southern Ethiopia
}

\author{
Tariku Olana $^{1} \quad$ Zerihun Demrew $^{2 *}$ \\ 1.Wondo Genet College of Forestry and Natural Resources, Hawassa University, P.O. Box 128, Shashemene, \\ Ethiopia \\ 2.College of Agriculture, Hawassa University, P.O. Box 05, Hawassa, Ethiopia
}

\begin{abstract}
The present study focused on identification of honey bee floras and their flowering times in Wondo Genet, Southern Ethiopia. Purposive sampling technique and combination of Rapid Rural Appraisal (RRA) tools were employed to identify the major and minor honey bee floras, and their flowering times. The data were collected from 36 sampled bee keepers in four peasant associations. Descriptive statistics and other statistical parameters were used in organizing, summarizing and describing the data. The average number of traditional, transitional and moveable frame beehives was $10.51 \pm 3.80,2.88 \pm 1.85$, and $1.12 \pm 1.21$, respectively. The average honey yield per harvest/colony was $5.1 \pm 0.72,13.20 \pm 0.92$ and $17.2 \pm 0.73 \mathrm{~kg}$ for traditional, transitional and moveable frame hives, respectively. Hence, there was a highly significant difference $(p<0.05)$ in terms of yield per hive/harvest between the three types of hives. A total of 47 bee flora species belonging to 42 genera and 30 families were identified by the sample respondents. The plant species were comprised of trees $(48.94 \%)$, shrubs $(27.66 \%)$, fruit trees $(10.64 \%)$, herbs $(6.38 \%)$ and food crops $(6.39 \%)$. Of the total number of bee flora plants identified in the study area, $17(36.17 \%)$ were major honey bee flora where as $30(63.83 \%)$ were the minor ones. The major parameters that the beekeepers used in identification of bee floras were flowers visited by honey bees. The beekeepers expressed that the frequency and number of bees visiting the flowers can help them to identify as the major and minor honey bee floras. The identified plant species bear flowers mainly from September to November and in March. The current investigation revealed that there are various plant species in the study area with different flowering times, and this will provide basic information for further researches focused on bee flora and their conservation strategies.
\end{abstract}

Keywords: bee flora, flowering time, honey bee, species

DOI: $10.7176 / \mathrm{JRDM} / 59-01$

Publication date:September $30^{\text {th }} 2019$

\section{Introduction}

Fossil evidence is sparse, but bees probably appeared on the planet about the same time as flowering plants in the Cretaceous period, 146 to 74 million years ago (Milner, 1996). Bees originally evolved from hunting wasps which acquired a taste for nectar and decided to become vegetarians (Milner, 1996). Honeybees (genus Apis) are social insects in the family Apidae, order Hymenoptera; and they are among the Aculeata Honey bees (Apis mellifera) are one of the most well-known, popular and economically beneficial insects. Engel (1999) review on Apis mellifera showed that there are 22 honey bee races in the world and 10 valid geographical races in Africa. Based on morphometric studies (Ruttner, 1986), the same number of honey bee races found in Africa. In Ethiopia, (Amsalu et al., 2004) reported five races of honey bees; A.m. jementica, A. m. scutellata, A. m. bondasii, A. m. monticola and A. m. woyi-gambella.

Beekeeping is a floral based industry and honey bee entirely depends on flowering plants. Out of 250,000 plant species available in the world, about 40,000 plant species are important food source for honey bees (Crane, 1990). Out of 6500-7000 flowering plants reported in Ethiopia, about 500 plant species are rich in nectar and pollen (Fichl and Admasu, 1994; Edwards, 1976) and the flowering plants comprising forest trees, shrubs, weeds and cultivated crops (Edwards, 1976). Abrol (1997) and Kumar (2015) reported that bee forage plants include fruit trees, vegetables, food crops, ornamental plants, herbs, shrubs, bushes, trees, forest and weeds. Honey production and other bee products depend on availability of floral resources and is a very important field for most beekeepers (Rucker et al., 2002). In honey production process, flowering plants provide nectar, pollen and other useful raw materials for bees and bees also serve them through pollination (Svensson, 1991). The plants that provided both pollen and nectar are named as bee pastures (Abrol, 1997). The availability of a large number of plant species provides surplus nectar and pollen to numerous types of honey bees making Ethiopia the best home for honey bees (Deffar, 1998). The performance of bee colony as well as honey, bee wax and other hive products depend on the availability of bee forage (Alemtsehay, 2011) and ecological suitability of the area (Nuru, 2002). However, the amount of nectar and pollen obtained significantly varies from plant to plant, season and time of the day (Crane, 1990).

The major and minor honey flow period depends on the available nectar and pollen (Atwal, 2001). In Ethiopia, herbaceous and shrubby honey plant flower after the big rainy season (September to November) while 
honey trees flower during the small rainy seasons of April to May (Amsalu, 2002). During the flowering period, there is a considerable movement of honey bees between plants of the same species. Usually a honey bee can visit between 50 to 1000 flowers in one trip, which takes between 30 minutes to 4 hours. For instance, in Europe, a bee can make between 7 to 14 trips a day. A colony with 25, 000 forager bees, each making 10 trips a day, is able to pollinate 250 million flowers (FAO, 2010). Honey bees are critically important for the function of ecosystem and the maintenance of agricultural production through their pollinating activities. In Ethiopia, an experiment was conducted to determine the effect of pollination on the Niger (Guizotia abyssinica) and the result showed that honey bees increased the seed yield of Niger by about 43\% (Admasu and Nuru, 2000) and Onion (Allume Cepa) by two folds (Admasu et al., 2008). Morse and Calderone (2000) estimated that honey bee increases yield of crops at about US\$ 14.6 billion. This shows that honey bees play an indispensable role in boosting agricultural productivity and biodiversity conservation.

Flowers of forest trees provide subsistence for honey bees and the trees physically provide shelter for a swarm or bee hives (Admasu et al., 2008). The existence of diverse floral resources coupled with variable climate and favorable ecological factors enable Ethiopia to sustain around ten million honey bee colonies (Amssalu et al., 2004). The highest number of bee colonies and surplus honey sources of flora make the country the leading producer of honey and beeswax in Africa (Gidey and Mekonen, 2010). Despite a surplus of honey bee flora, the forest resource base of the country is decreasing in the course of time (Deffar, 1998). Expansion of agricultural land, fuel wood collection and timber harvesting are resulting in shortage of bee forage (Deffar, 1998). The reduction of plant species that provide nectar and pollen make difficult to maintain bee colonies (Kerealem, 2005) and affect the diversity of honey bee forage plants (Gidey and Mekonen, 2010). Similarly, Ayalew (2006) pointed out that the loss of bee forage species affects the life pattern, products and productivity of honey bees in Ethiopia.

Wondo Genet watershed had so long known for its rich biodiversity and high agricultural productivity. It is one of the prestigious areas in Ethiopia where remnant natural forest maintained. Nevertheless, forest cover has been declining at an alarming rate in the area. Expansion of agricultural land, fuel wood collection, timber production and population pressure are found to be among the causes of forest degradation in the area. In Wondo Genet area small holder bee keepers have knowledge in identifying honey bee floras and flowering times. The plants visited by honey bees can be identified through direct observation of foraging worker bees (Ayansola and Davies, 2012); Phenological analysis of honey bee (Adekanmbi and Ogundipe, 2009) and analysis of pollen loads removed from returning foragers (Köppler et al., 2007. Beekeepers knowledge in bee flora identification and flowering time through direct observation help them to identify honey harvesting seasons and maximum honey production (Rajan, 1980). Dalio (2013) also reported that the knowledge of honey bees foraging behavior and their flora is essential for management of beekeeping. The honey bee flora of Wondo Genet area has not been well documented. Hence, this study aimed at documenting honey bee floras and their flowering times in Wondo Genet, Southern Ethiopia.

\section{Materials and Methods}

\subsection{Description of study area}

The study was conducted in Wondo Genet catchment, Southern Ethiopia. Wondo Genet catchment is located 264 $\mathrm{km}$ south of Addis Ababa, the capital city of Ethiopia (figure 1). It is located within $7006^{\prime} \mathrm{N}$ latitude and 380 37 ' E longitudes. The study area catchment covers wider areas with very few remnant natural forests. This remnant forests are located at the foot of the main eastern escarpment of the Ethiopian Rift Valley. It is part of a narrow moist belt ecological zone which lies between the lake area semi-arid woodland and the Arsi western escarpment undifferentiated Afromontane forests (Negash et al., 2014). The major tree species found in Wondo Genet are Celtis africana, Cordia africana, Croton macrostachyus, Albizia gumifera, Podocarpus falcatus, Milletia sp. and others. Besides, plantation forests include Eucalyptus spp., Pinus patula, Grevillea robusta and Juniperus procera (Eshetuand Högberg, 2000). The elevation gradient of Wondo Genet ranges between 1700 and 2600 meters above sea level with annual rainfall of $700-1400 \mathrm{~mm}$ and mean temperature of about $19^{\circ} \mathrm{C}$ (Belaynesh, 2002).The area is one of the most densely populated area and the livelihoods of people depend on subsistence mixed farming system, which includes crop production and livestock husbandry. 


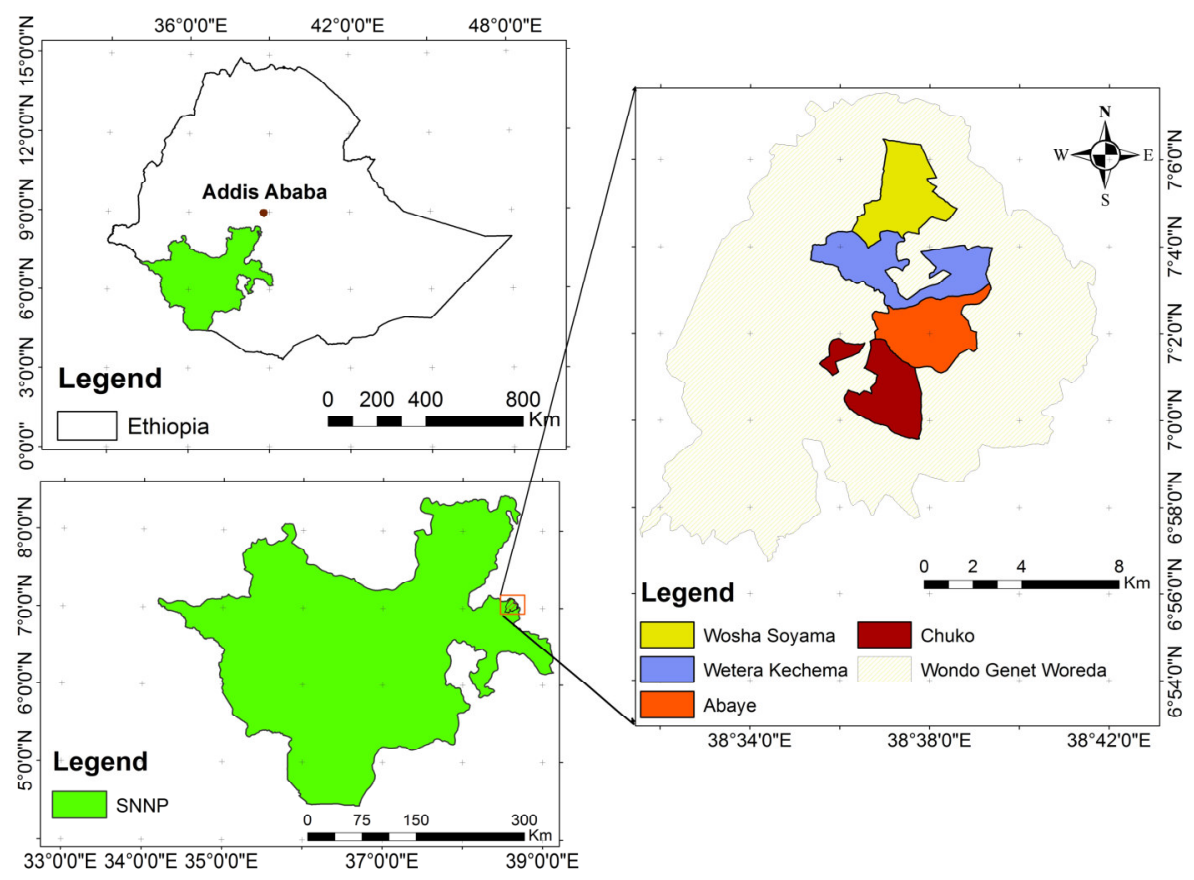

Figure 1. Location of the study area

\subsection{Data collection method}

Data collection and documentation on honey bee floras and their flowering times were carried out between October 2016 and December 2017. The data collection methods include key informant interviews, group discussion, semi-structured questionnaires and individual interviews. The key informants for this study was selected by the development agents, Peasant Associations (PA) chairman and other farmers involved during the initial meeting with PAs administrative committees. A purposive sampling strategy was used in selecting the participants for discussion, questionnaires and interviews. Attention was given not to limit the ideas of the participants. During the time of group discussions and individual interviews, participants were encouraged to express their ideas and discuss freely whatever points they thought were essential.

Four community level discussions were held in four PAs; Wosha Soyama, Chuko, Abaye and Wetera Qetema. Overall, 36 beekeepers participated in group discussions and interviews from the four selected PAs. In group discussion participants were selected by considering experience and active participation in beekeeping activities. Group discussions were focused on honey production systems, knowledge of farmers in identification of bee flora, socioeconomic characteristics of beekeepers and multipurpose function of bee floras. Direct observation was also made on special issues like beekeeping practices, plant species managed as bee forage and other activities related to beekeeping. The information and data captured through observation were useful in triangulation

\subsection{Data analysis}

Descriptive statistics and other statistical parameters were used in organizing, summarizing and describing the data. Statistical package for social sciences (SPSS) and Microsoft-Excel were used to analyze the collected data systematically. The results from various methods were equated to check the reliability of the collected data.

\section{Results and Discussion}

\subsection{Socioeconomic characteristics of respondents}

The present investigation revealed that majority of respondents was in the reproductive age group (42.03 years old). Aged persons as old as 70 years were also involved in beekeeping activities (table 1). Assfea (2009) reported an average of 45.6 years old for beekeepers in the North Ethiopia. The result of our investigation were also in line with Nuru (2007) which states that beekeeping has an advantages of being practiced by aged men and persons with disabilities. Average family size of the study area was 7 which is higher than the national average rural family size of 5.13 (CSA, 2014). It indicates the presence of high fertility rate. The average land holding was 0.73 ha per household which is less than the national average of 1.17 ha per. The long beekeeping experiences in the study area contributed for the management of tree species. During group discussion, framers who had long experience in honey production observed to have better understanding about the benefits of beekeeping activities. The result of our investigation showed that there is a strong association between 
beekeeping experience and knowledge in the identification of bee flora and their flowering time.

Table 1: Average age, beekeeping experience, family size and land holding of the sample respondents in the study area

\begin{tabular}{llllll}
\hline Variables & $\mathrm{N}$ & Minimum & Maximum & Mean & Std. Deviation \\
\hline Age of respondent & 36 & 21.00 & 70.00 & 42.03 & 12.72 \\
Beekeeping experience & 36 & 5.00 & 35.00 & 17.06 & 8.50 \\
House hold size & 36 & 3.00 & 12.00 & 7.00 & 2.20 \\
Land size & 36 & .30 & 1.50 & .75 & .38
\end{tabular}

Regarding educational status of households, 38.91\% of respondents never attained any formal education where as only few respondents completed secondary school (table 2). The educational status of households in the study area would have a negative implication on acceptance of new technologies. In farming community with low level of literacy, extension and research work to improve the production process is hardly possible. Rehima et al. (2013) investigated the effect of farmers' literacy level on crop management and diversification and recommended the need for farmers' education. From the sample respondents $13.89 \%$ were female and $86.11 \%$ male. The result showed, unequal participation of males and females in bee keeping activities. It agrees with the findings of Adebabay (2008) and Workeneh et al. (2011) who reported low level of females' participation in beekeeping activities in Ethiopia. From the sampled respondents $75 \%$ have access to extension and all of them had no access to credit services. Feder et al. (1985) reported that the availability of credit facilitates enable farmers to purchase inputs or acquire physical capital needed for technology adoption. Lack of access to credit hindered the farmers to participate in improved beekeeping technologies and decrease honey production.

Table 2: Education status, sex, wealthy, access to extension and credit of the sample respondents in the study area

\begin{tabular}{cccc}
\hline Variables & & Frequency & Percent \\
\hline & No education & 14 & 38.91 \\
& Primary education & 14 & 38.89 \\
Education status & Secondary education & 6 & 16.67 \\
& $12+1$ & 2 & 5.56 \\
\hline Sex & Male & 31 & 86.11 \\
& Female & 5 & 13.89 \\
\hline \multirow{2}{*}{ Wealthy } & Poor & 8 & 22.22 \\
Access to extension & Medium & 21 & 58.33 \\
Access to credit & Rich & 7 & 19.44 \\
\hline
\end{tabular}

\subsection{Factors affecting beekeeping experience}

The coefficient of determination $\left(\mathrm{R}^{2}\right)$ of 0.77 in the present investigation indicates that the model explains the variations in beekeeping experience very well. The result of the Ordinary Least Square regression analysis model showed that beekeeping experience was affected by age positively at $1 \%$ significant level (table 3 ). The influences of other factors like education and marital status on beekeeping activities were not significant.

Table 3: Factors affecting beekeeping experience

\begin{tabular}{lllll}
\hline Beekeeping experience & Coef. & Std. Err. & $\mathrm{t}$ & $\mathrm{P}>\mathrm{t}$ \\
\hline Age & 0.61 & 0.08 & 8.03 & $0.00^{*}$ \\
Sex & 2.28 & 2.59 & 0.88 & 0.39 \\
Education status & 0.58 & 0.80 & 0.72 & 0.48 \\
Marital status & -0.65 & 4.08 & -0.16 & 0.88 \\
Access to extension & 0.04 & 1.69 & 0.02 & 0.98 \\
Wealth & -0.07 & 1.19 & -0.06 & 0.95 \\
cons & -10.43 & 11.84 & -0.88 & 0.39 \\
\hline
\end{tabular}

*significant at $1 \%$ probability level

\subsection{Beekeeping activities in Wondo Genet area}

Farmers in the study area observed to use three different types of beehives (table 4) for honey production and the majority of farmers placed their beehives at the backyard. The result of the study showed that the average number of bee colonies for traditional, transitional and movable frame beehives were $10.51 \pm 3.80,2.88 \pm 1.85$, 
$1.12 \pm 1.21$, respectively. It is found that majority of the beekeepers depends on traditional honey production systems characterized by low productivity. The result corresponds to previous studies conducted in the northern, south western and central parts of Ethiopia (Kebede and Lema, 2007; Nuru, 2007). A similar result was also reported from Tanzania where $99 \%$ of the hives owned by the farmers were traditional ones (Match, 2007).

Table 4: Type of beehives owned by sample respondents

\begin{tabular}{|c|c|c|}
\hline \multirow[b]{2}{*}{ Beehive types } & \multicolumn{2}{|c|}{ Sample size $=36$} \\
\hline & Frequency & percentage \\
\hline Traditional hive & 17 & 47.22 \\
\hline Transitional hive & 6 & 16.67 \\
\hline Movable frame hive & 5 & 13.89 \\
\hline Traditional and transitional & 2 & 5.56 \\
\hline Transitional and movable frame hives & 2 & 5.56 \\
\hline Traditional, transitional and movable frame hives & 4 & 11.11 \\
\hline
\end{tabular}

\subsection{The productivity of bee hives}

The present investigation revealed an average honey yield per harvest/colony of $5.1 \pm 0.72,13.20 \pm 0.92$ and $17.2 \pm 0.73 \mathrm{~kg}$ for traditional, transitional and moveable frame hives, respectively. Movable frame hives were more productive followed by transitional and traditional beehives (figure 2). Hence, there was a highly significant difference $(p<0.05)$ in terms of yield per hive/harvest between the three types of hives. The result was in line with the national average of $5 \mathrm{~kg}$ (Gezahegne, 2001), 12-15 kg and 15-20kg (MOA, 2003) for traditional, transitional and movable frame bee hives, respectively. Tessega (2009) reported that the average amount of honey harvested from traditional, transitional and frame hives were $8.94 \mathrm{~kg}, 10.66 \mathrm{~kg}$ and $15.56 \mathrm{~kg}$, respectively. In addition, Edessa (2005) reported an average honey yield of traditional hive $6.1 \mathrm{~kg}$ per hive in West Showa Zone, Ethiopia.

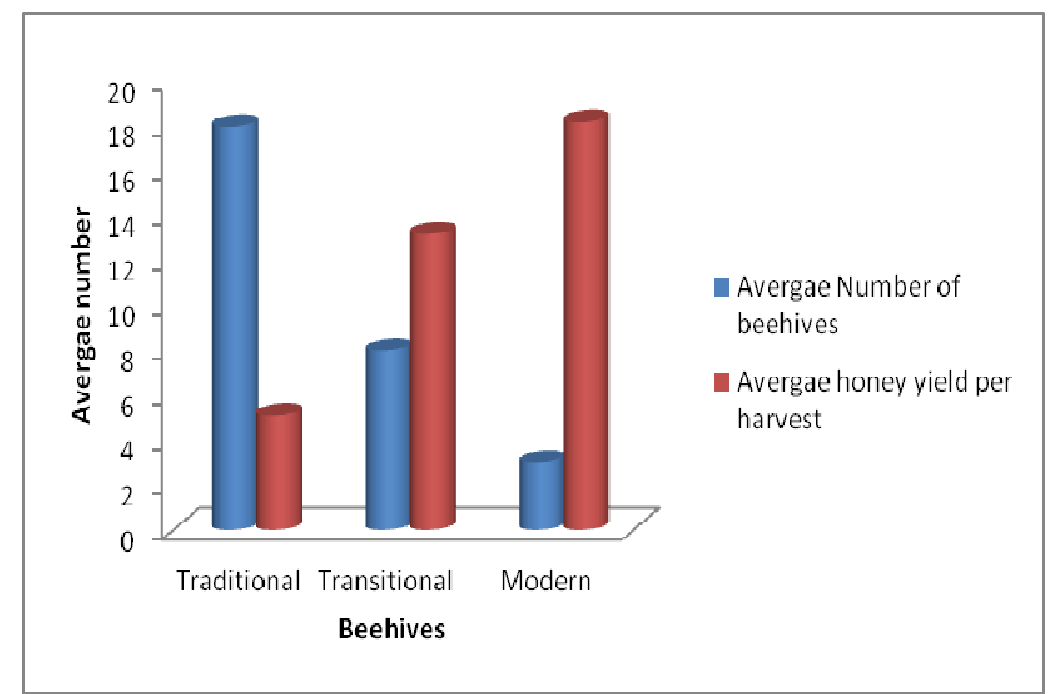

Figure 2: The association between average number of beehives and honey yield

\subsection{Identification of honey bee floras and their flowering times}

A total of 47 bee flora species belonging to 42 genera and 30 families were identified in the study area. Fabaceae was leading family with 6 species, followed by Myrtaceae, Papilionaceae and Rosaceae each having 4 species (table 5). Out of the total species identified, 17 (36.17\%) and $30(63.83 \%)$ were major and minor bee flora species, respectively. Regarding the life form of plant species, it is revealed that trees constituted the highest proportion (48.94\%) of the identified species followed by shrubs and fruits trees (figure 3). Amsalu (1996) reported that plant species growing naturally occupies quite large in variety proportions than cultivated crops. 
Table 5: Major and minor honey bee flora identified by respondents in study area

\begin{tabular}{|c|c|c|c|c|}
\hline Scientific name & Family name & Life form & Flowering time & Major/minor \\
\hline Acacia abyssinica & Fabaceae & Tree & June & 1 \\
\hline Acacia mearnsii & Fabaceae & Tree & June & 1 \\
\hline Albizia gummifera & Fabaceae & Tree & February & 1 \\
\hline Bidens prestinaria & Asteraceae & Shrub & September-October & 1 \\
\hline Brassica intergrifolia & Brassicaceae & Shrub & June-July & 2 \\
\hline Callistemon citrinus & Myrtaceae & shrub & July-August & 1 \\
\hline Carica papaya & Caricaceae & Fruit Tree & March & 2 \\
\hline Citrus aurantifolia & Rutaceae & Fruit tree & March & 2 \\
\hline Citrus sinensis & Rutaceae & Fruit tree & March & 2 \\
\hline Coffea arabica & Rubiaceae & Shrub & February-March & 1 \\
\hline Cordia africana & Boraginaceae & Tree & June-July & 1 \\
\hline Croton macrostachyus & Euphorbiaceae & Tree & April-May & 1 \\
\hline Cucurbita pepo & Cucurbitaceae & Herbs & September & 2 \\
\hline Dodonaea angustifolia & Spaindaceae & Tree & October & 2 \\
\hline Dovyalis abyssinica & Flacourtiaceae & shrub & March & 2 \\
\hline Eriobotrya japonica & Rosaceae & Tree & November & 2 \\
\hline Erythrina abyssinica & Papilionaceae & Tree & October & 2 \\
\hline Erythrina brucei & Papilionaceae & Tree & October & 2 \\
\hline Eucalyptus species & Myrtaceae & Tree & May- June & 1 \\
\hline Ficus vasta & Moraceae & Tree & August & 1 \\
\hline Grevillea robusta & Proteaceae & Tree & August & 2 \\
\hline Hypoestes forskaolii & Acanthaceae & Shrub & December & 2 \\
\hline Jacaranda mimosifolia & Bignoniaceae & Tree & August & 2 \\
\hline Juniperus procera & Cupressaceae & Tree & February & 1 \\
\hline Lantana camara & Verbenaceae & Herb & July-August & 2 \\
\hline Leucaena leucocephala & Fabaceae & Shrub & November - January & 2 \\
\hline Mangifera indica & Anacardiaceae & Tree & January- February & 1 \\
\hline Maytenus obscura & Celastraceae & Shrub & November & 2 \\
\hline Maytenus undata & Celastraceae & Shrub & March & 2 \\
\hline Medicago sativa & Fabaceae & Herbs & October- November & 2 \\
\hline Melia azedarach & Meliaceae & Tree & October & 2 \\
\hline Moringa stenopetala & Moringaceae & Shrub & September & 2 \\
\hline Musa spp. & Musaceae & Fruit tree & December & 2 \\
\hline Olea europaea & Oleaceae & Tree & July-August & 1 \\
\hline Persea americana & Lauraceae & Fruit tree & March-April & 1 \\
\hline Phaseolus vulgaris & Fabaceae & Legume crop & June & 2 \\
\hline Prunus Africana & Rosaceae & Tree & September & 2 \\
\hline Rapanea melanophloeos & Myrsinaceae & Tree & June & 2 \\
\hline Rosa abyssinica & Rosaceae & Shrub & November & 2 \\
\hline Schefflera abyssinica & Araliaceae & Shrub & November & 2 \\
\hline Sesbania sesban & Papilionoideae & Shrub & November -January & 2 \\
\hline Shinus molle & Anacardiaceae & Tree & March & 1 \\
\hline Syzygium guineense & Myrtaceae & Tree & January & 2 \\
\hline Vernonia amygdalina & Asteraceae & Tree & August-September & 1 \\
\hline Vernonia auriculata & Asteraceae & Tree & March & 1 \\
\hline Vicia faba & Fabaceae & Pulse crop & September & 2 \\
\hline Zea mays & Poaceae & Cereal crop & July-August & 2 \\
\hline
\end{tabular}

Note: 1 is major while 2 is minor bee flora 


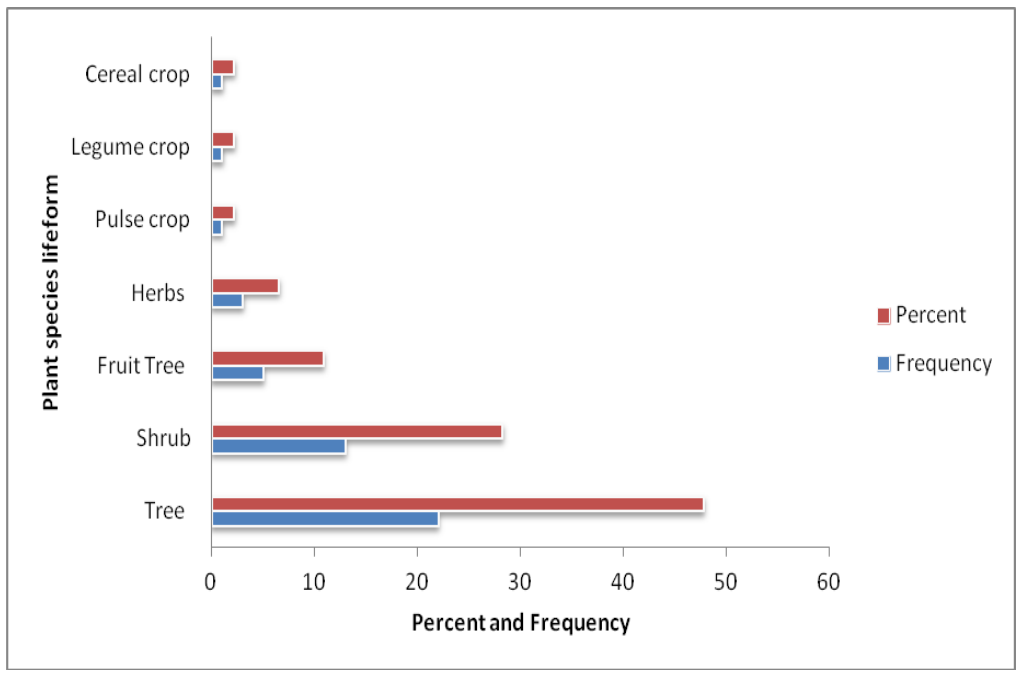

Figure 3: Percent and frequency of plant species life form

Adequate knowledge of the bee floras and flowering times are the prerequisite for establishing an apiary site. In the study area, it is found that almost all beekeepers were having significant knowledge in identification of bee floras and flowering times. One of the major parameters that the beekeepers used in identification of bee flora was the intensity of flowers visited by honey bees. The beekeepers expressed that the frequency and number of bees visiting the flowers can help them to identify as the major and minor honey bee flora. When a large number of bees visited the flowers, particularly in the morning and afternoon they identified as major honey bee floras. On the other hand, when flowers are visited by less number of honey bees and their frequency is less then they categorized as minor ones. The knowledge in the identification of the bee flora helps the beekeepers in recognizing the honey harvesting season and management of beehives. Amsalu (2004) and Admasu et al. (2004) witnessed that the knowledge of floral calendar helps the bee keepers in deciding different beekeeping activities. The study area has huge potential for honey production. November and December are the major honey harvesting time followed by March and April.

\subsubsection{Preference ranking of major honey bee flora}

Preference ranking of bee floras for honey production was performed through group discussion and key informant interviews. From 16 major bee floras identified, 10 of them were named as top ten at each study site (table 6). Bidens prestinaria, Croton macrostachyus, Cordia africana, Coffea Arabica, and Callistemon citrinus and Vernonia amygdalina were the most highly appreciated bee floras.

Table 6: Preference ranking of major bee floras for honey production (1 to 10 from highly to less preferred).

\begin{tabular}{|c|c|c|c|c|c|}
\hline \multirow[t]{2}{*}{ Plant species } & \multicolumn{4}{|c|}{ Rank per peasant association } & \multirow{2}{*}{$\begin{array}{c}\text { Frequency } \\
(\%) \text { of } \\
\text { appreciation }\end{array}$} \\
\hline & $\begin{array}{c}\text { Wosha } \\
\text { Soyama }\end{array}$ & Abaye & Chuko & $\begin{array}{l}\text { Wetera } \\
\text { Qetema }\end{array}$ & \\
\hline Acacia abyssicnica & 8 & 7 & & & 50 \\
\hline Bidens perstinaria & 1 & 1 & 1 & 1 & 100 \\
\hline Callistemon citrinus & 6 & 4 & 7 & 5 & 100 \\
\hline Coffee arabica & 1 & 2 & 1 & 2 & 100 \\
\hline Cordia africana & 1 & 2 & 1 & 1 & 100 \\
\hline Croton macrostachyus & 1 & 1 & 1 & 2 & 100 \\
\hline Eucalyptus species & 4 & 5 & & 4 & 75 \\
\hline Ficus vasta & 6 & 4 & 10 & & 75 \\
\hline Persea americana & 3 & 2 & & 4 & 75 \\
\hline Vernonia amygdalina & 1 & 2 & 1 & 3 & 100 \\
\hline
\end{tabular}

\subsubsection{Preference ranking of minor honey bee flora}

Preference ranking of minor bee flora for honey production was also pointed out through group discussion. From 30 minor bee floras, 10 of them were named as top ten (table 7). Dovalis abyssinica, Mangifera indica, Musa spp and Zea mays were the top ranked minor bee floras. 
Table 7: Preference ranking of minor bee floras for honey production (1 to 10 from highly to less preferred).

\begin{tabular}{|c|c|c|c|c|c|c|c|}
\hline \multirow[b]{2}{*}{ Plant species } & \multicolumn{6}{|c|}{ Rank per peasant association } & \multirow{2}{*}{$\begin{array}{l}\text { Frequency } \\
(\%) \text { of appreciation }\end{array}$} \\
\hline & Wosha & Soyama & Abaye & Chuko & Wetera & Qetema & \\
\hline Carica papaya & & 5 & 7 & 6 & & 7 & 100 \\
\hline Dovalis abyssinica & & 2 & 3 & 3 & & 1 & 100 \\
\hline Ficus vasta & & 6 & 4 & 9 & & & 75 \\
\hline Grevilla robusta & & 5 & 7 & 4 & & & 75 \\
\hline Hypoestes forskali & & 5 & 7 & 4 & & & 75 \\
\hline Mangifera indica & & 4 & 6 & 2 & & 3 & \\
\hline Musa spp & & 8 & 5 & 9 & & 7 & 100 \\
\hline Schefflera abyssinica & & 9 & & 7 & & & 50 \\
\hline Maytenus undata & & 7 & & & & & 25 \\
\hline Zea mays & & 6 & 8 & 10 & & 7 & 100 \\
\hline
\end{tabular}

\subsection{Availability of bee flora and strength of bee colony}

The beekeepers expressed the presence of significant relationship between bee flora availability and strength of the bee colony. When large number of flower blooms the bee colonies are very strong and less likely affected by honey bee enemies. Bista and Shivakoti (2001) reported that honey bee colony strength as well as honey production depends on the availability and bee flora management. Apiary sites established in close proximity of good bee forage are productive and have high colony strength (Jacobs et al., 2006). In the study are the majority bee floras mainly bearing flower from September to November and in March (Figure 4). This indicates the peak period for honey flow in Wondo Genet area. Our investigation was in line with previous study conducted in Ethiopia by Fichtl and Admasu (1994). Furthermore, flowering calendar helps to identify shortage of bee forage season. In the month of January, April and May there is a shortage of bee flora in the study area. Accordingly, the beekeepers provide supplementary feed mainly from mid December to January (81.4\%) followed by April to May (18.6\%). In addition, respondents reported to leave a certain amount of honey un-harvested (89. 8\%) and plant bee forage (10.2\%) around their apiary sites to alleviate shortage of bee forages.

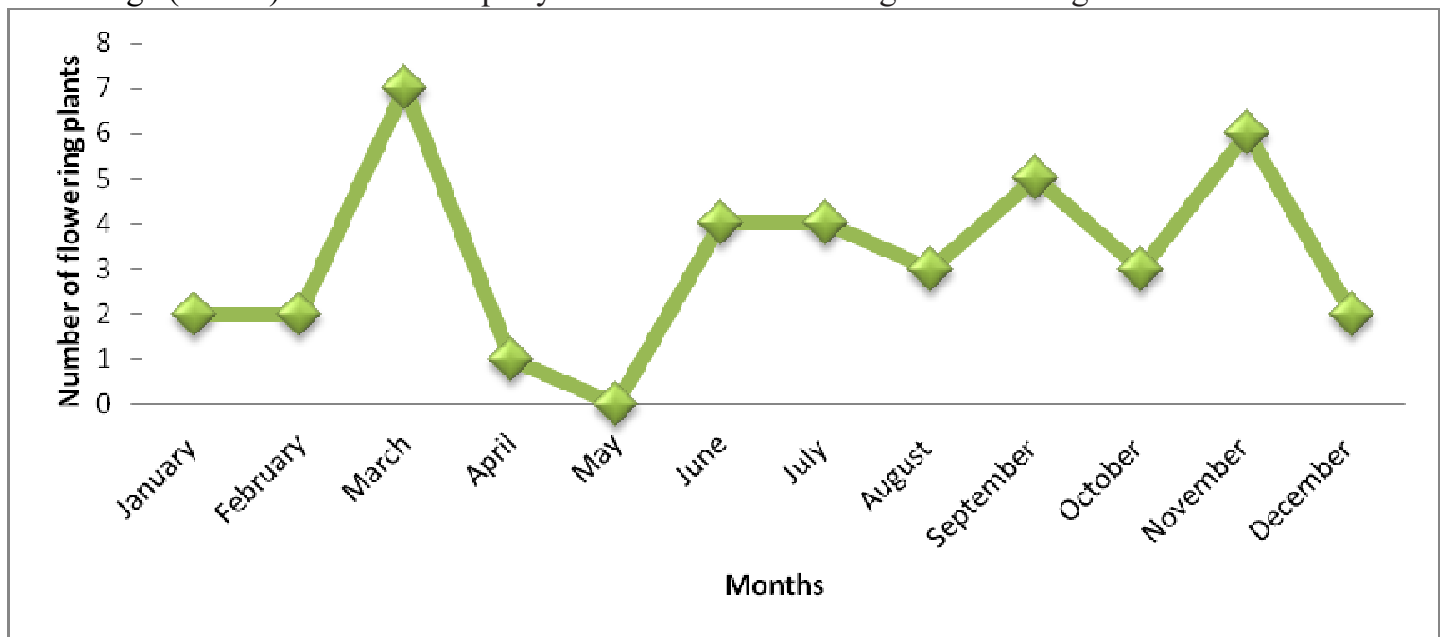

Figure 4: Flowering months of bee forage in the study area

\subsection{Multipurpose functions of tree species}

The current investigation revealed that trees and shrubs are very important components of agroforestry system in the study area. They play multiple functions in the systems (table 8). In addition to bee forage, trees and shrubs provide the beekeepers with wood products as well as maintaining and enhancing the physical condition of the study area to sustain agricultural crop production. The multipurpose trees identified by the respondents provide different function like soil conservation, soil fertility management, shade, firewood, timber and livestock feed. Trees species like Cordia african, Albizzia gummifera and Olea europaea were also an important source of income for farmers as wood can be sold as timber. 
Table 8: Multipurpose functions of tree species for beekeepers in study area Plant Species

Multipurpose function of plant species

\begin{tabular}{lllllll}
\hline BF & SC & SFM & Sh & FW & Ti & LF
\end{tabular}

Acacia abyssinica

Albizzia gummifera

Cordia africana

Croton macrostachyus

Eucalyptus species

Ficus vasta

Leucaena leucocephala

Olea europaea

Sesbania sesban

Vernonia amygdalina

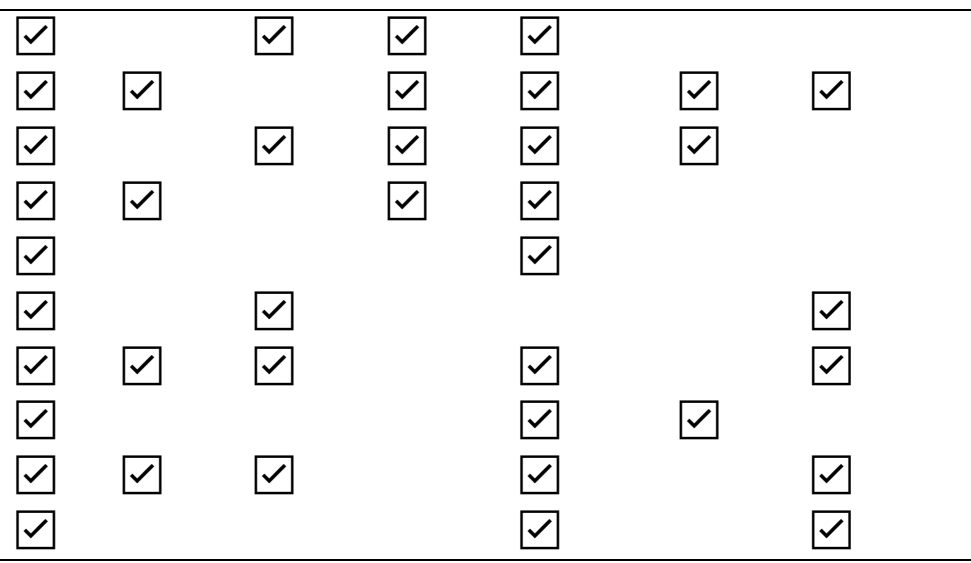

Note: $\mathrm{BF}=\mathrm{Bee}$ forage, $\mathrm{SC}=$ Soil conservation, $\mathrm{SF}=$ Soil Fertility Management, $\mathrm{Sh}=\mathrm{Shade}, \mathrm{FW}=$ Fire Wood, $\mathrm{Ti}=$ Timber, $\mathrm{LF}=$ Livestock Feed

\section{Conclusion}

The plant species identified in the study area supports large number of bee colonies. Availabilities of bee floras are very critical for the establishment of an apiary sites. Adequate knowledge of beekeepers in identification of bee flora and flowering time play an important role in apiculture development and honey production system. The plant species identified as major and minor honey bee floras were belonging to different families. Fabaceae was leading family with 6 species, followed by Myrtaceae, Papilionaceae, Rosaceae (4 species each). Bidens prestinaria, Croton macrostachyus, Cordia africana, Coffee Arabica, and Callistemon citrinus and Vernonia amygdalina were among the major honey bee floras identified, whereas Dovalis abyssinica, Mangifera indica, Musa spp and Zea mays were identified as minor bee floras. The knowledge in the identification of honey bee flora and their flowering time helps the beekeepers to recognize the honey harvesting season and management of the beehives. Bee colony strength and honey production depends on the availability of bee floras. The study also highlighted that some of the identified plant species have a significant role in maintaining and enhancing the physical condition of the study area to sustain crop production. The present investigation will provide basic data for further researches more focus on bee flora studies and their conservation strategies.

\section{References}

Abrol, D.P. (1997). Bees and Bee-Keeping in India, Edn1, Kalyani Publishers, New Delhi, 110-130.

Adebabay, K., Kerealem, E., Tessema, A. and Abebe, J. (2008). Assessment of the status of beekeeping in Amhara region. Amhara Regional Research institute, Bahirdar Ethiopia. Pp 32-35.

Adekanmbi, O., Ogundipe, O. (2009). Nectar Sources for the honey bee (Apis mellifera adansonii) revealed by pollen content. Not. Bot. Horti Agrobot. Cluj-Napoca, 37(2), 211-217.

Admasu, A. and Debissa, L. (2008). Bee plant inventory and the Beekeeping potentiality of Menagesha Suba state forest. Journal of Biological Society of Ethiopia, 8(2), 85-97, 2009.

Admasu, A., and Nuru, A. (2002). Effect of Honeybee Pollination on Seed Yield and Oil Content of Niger (Guizotia abyssinica). Proceedings of the first National Conference of Ethiopian Beekeepers Association, Addis Ababa, Ethiopia.

Alemtsehay, T. (2011). Seasonal Availability of Common Bee Flora in Relation to Land Use and Colony Performance in Gergera Watershed Atsbi Wenberta District Eastern zone of Tigray, Ethiopia. MSc thesis, Hawassa University, Ethiopia.

Amsalu, B. (1996). Preliminary study on honey plants around Holeta. Holleta Bee Research and Training Center, Holeta, Ethiopia.

Amsalu, B. (2002). Multivariate morphometric analysis and behavior of Honeybees (Apis mellifera L.) in the Southern Regions of Ethiopia. Ph.D dissertation. Rhodes University, Department of Zoology and Entomology, South Africa.

Amsalu, B., Nuru, A., Randall, H.R. and Sara, R. (2003). Morphometric analysis of Ethiopian honeybees. Apidologie, 35:71-81.

Amsalu, B., Nuru, A., Radloff SE. and Hepburn, H.R. (2004). Multivariate morphometeric analysis of honeybees in the Ethiopian region. Apidologie, 35, 71-81. 
Assefa, A. (20009). Market chain analysis of honey production: in atsbiwemberta district, eastern zone of tigray national regional state, MSc thesis. Haramaya University, Ethiopia.

Atwal, A.S. (2001). Essentials of Beekeeping and Pollination, Edn1, Kalyani Publishers, New Delhi, 201-218.

Ayalew, K. (2006). The loss of some natural plant species in Tigray and the concern to the living conditions of honeybees. loss of natural plants: Proceedings of the 5th Annual National Conference of Ethiopian Beekeepers Association. Pp 8-15.

Ayansola, A. A., Davies, B.A. (2012). Honeybee floral resources in southwestern Nigeria. J. Biol. Life Sci. 3(1), $127-138$

Belaynesh, Z. (2002). Perceptions of Forest Resource Changes in and around Wondo Genet Catchment and Its near Future Impacts, MSc thesis, Wondo Genet College of Forestry, Ethiopia.

Bista, S. and Shivakoti, P. G. (2001). Honeybee flora at Kabre Dolakha District. Journal of Napal Agricultural Research, 5, 16-25.

Crane, E. (1990). Bees ad Beekeeping: Science, Practice and World Resources. Comstock Publishing Associates (Cornell University Press), Ithaca, New York.

CSA (Central Statistical Authority). (2014). Agricultural sample survey (2013/2014): Report on land utilization (private peasant holdings, meher season), Volume IV. Statistical Bulletin no. 573. The federal democratic republic of Ethiopia. Addis Ababa, Ethiopia.

Dalio, J. S. (2013). Foraging activity of Apis mellifera on Parthenium hysterophorus. ISOR ,Journal of Pharmacy and Biological Sciences, 7(5), 1-4.

Deffar, G.. (1998). Non-Wood Forest Products in Ethiopia. EC-FAO Partnership Programme (1990- 2000). Addis Ababa. Pp 1-5.

Edessa, N. (2005). Survey of honey production system in West Shewa Zone: Proceedings of the $4^{\text {th }}$ Ethiopian Beekeepers Association (EBA).

Edwards, S. (1976). Some wild flowering plants of Ethiopia. Addis Ababa University press, Addis ababa, Ethiopia.

Ejigu, K., Gebey T., and Preston, T. (2009). Constraints and prospects for apiculture research and development in Amhara region, Ethiopia. Livestock Research for Rural Development. 21.

Engel, M.S. (1999). The taxonomy of recent and fossil honeybees (Hymenoptera: Apidae; Apis ). J Hymen Res, $8(2), 165-196$.

Eshetu, Z. and Hogberg, P. (2000). Reconstruction of forest site history in Ethiopian highlands based on $\mathrm{C}^{13}$ natural abundance of soils. Ambio, 29, $83-89$.

FAO (Food and Agriculture Organization of the United Nations). (2009). Bees and their role in forest livelihoods: A guide to thne services provided by bees and the sustainable harvesting, processing and marketing of their products by Nicola Bradbear. Paper 19, Pp 204.

FAO (Food and Agriculture Organization of the United Nations). (2010). FAOSTAT database on Agriculture and Nutrition. Food and Agricultural Organization of the United Nations, Rome, Italy.

Feder, L., Just, R.E., and Zilberman, O. (1985). Adoption of Agricultural Innovationin Developing Countries:”A Survey" Economic Development and Cultural Change, 32(2), 255-298.

Fichtl, R., and Admasu, A. (1994). Honey bee flora of Ethiopia. The National Herbarium, Addis Ababa University and Deutscher Entwicklungsdieenst (DED) Mergaf Verlag, Germany.

Gezahegne, T. (2001). Marketing of honey and beeswax in Ethiopia: past, present and perspective features: Proceedings of the third National Annual Conference of the Ethiopian Beekeepers Association (EBA), September 3-4, 2001, Addis Ababa, Ethiopia, Pp 78-88.

Gidey, Y., Mekonen, T. (2010). Participatory Technology and Constraints Assessment to Improve the Livelihood of Beekeepers in Tigray Region, Northern Ethiopia. MEJS 2(1), 76-92.

Jacobs, F., Simoens C., Graaf, D. and Deckers, J. (2006). Scope for non-wood forest products income generation from rehabilitation areas: focus on beekeeping. Journal of the Drylands 1, 171-185.

Kebede, T. and Lemma, T. (2007). Study of honey production system in Adami Tulu Jido Kombolcha district in mid rift valley of Ethiopia. Livestock Research for Rural Development, 19, 162.

Kerealem, E. (2005). Honeybee production system, opportunities and challenges in Enebsesarmidir woreda (Amahara region) and Amaro special woreda(SNNPR),Ethiopia, MSc. thesis, Alemaya University, Ethiopia.

Köppler K, Vorwohl, G, Koeniger, N. (2007). Comparison of pollen spectra collected by four different subspecies of the honey bee Apis mellifera. Apidologie, 38, 341-353.

Kumar, D., Bharti, U. (2015). Tropic Niche Specialization of Buteamonosperma from Chandigarh. Journal of Entomology and Zoology Studies, 3(4), 83-85.

Match, M. (2007). Honey and beeswax value chain analysis in Tanzania: Study commissioned by TRAIDCRAFT and SME competitiveness facility and conducted by Mach Maker Associates Limited.

Milner, A. (1996). An introduction to understanding honeybees, their origins, evolution and diversity. www.bibba.con/origins_milner.php/. 
MOA (Ministry of Agriculture). (2003). Comprehensive bees and beeswax marketing, $2^{\text {nd }}$ draft. MOA, Addis Ababa, Ethiopia.

Morse, R., Calderone, N. (2000). The value of honeybees as pollinators of US crops in 2000. Bee Culture, Pp.115.

Negash, M., Kelboro, G. (2014). Effects of Socio-Economic Status and Food Consumption Pattern on Household Energy uses: Implications for Forest Resource Degradation and Reforestation around Wondo Genet Catchments, South-Central Ethiopia. Eastern Africa Social Science Research Review, Volume 30, Pp. 27-46.

Nuru, A. (2002). Geographical races of the Honeybees (Apis mellifera L.) of the Northern Regions of Ethiopia, $\mathrm{Ph} . \mathrm{D}$ dissertation. Rhodes University, South Africa.

Nuru, A. (2007). Atlas of pollen grains of major honey bee flora of Ethiopia. Holeta, Ethiopia, Pp,121.

Rajan, B. K. (1980). Apiculture and farm forestry in semi-arid tracts of Karnataka. Proceedings of second international conference on apiculture in tropical climates. New Delhi. India. Pp.187-89.

Rehima, M., Belay, K., Dawit, A. and Rashid, S. (2013). Factors affecting farmers' crops diversification: Evidence from SNNPR, Ethiopia. International Journal of Agricultural Sciences, 3(6), 558-565.

Rucker, R., Walter, N., and Michael, B. (2002). The economics of honeybee pollination markets. Montana State university.USA. Pp.1-4.

Ruttner, F. (1986). Geographical variability and classification: Rinderer, T.E. (ed.), Bee Genetics and Breeding. Academic Press Inc., Orlando, U.S.A. Pp. 23-34.

Svensson, B. (1991). Bees and trees. Swedish University of Agricultural science, International Rural Development Center Working Paper 183, 1100-8679.

Tessega, B. (2009). Honeybee Production and Marketing Systems, Constraints and Opportunities in Burie District of Amhara Region, MSc thesis, Bahirdar University, Ethiopia.

Workneh, A. (2011). Identification and documentation of indigenous knowledge of beekeeping practices in selected districts of Ethiopia. Journal of Agricultural Extension and Rural Development, 3(5), 82-87. 